\title{
Demographic patterns of the purple sea urchin Strongylocentrotus purpuratus along a latitudinal gradient, 1985-1987
}

\author{
Thomas A. Ebert* \\ Department of Biology, San Diego State University, San Diego, California 92182-4614, USA \\ Present address: Department of Zoology, Oregon State University, Corvallis, Oregon 97331-2914, USA
}

\begin{abstract}
The abundant center model of geographic distribution has been tested for the purple sea urchin by others who found highest densities and reproduction towards the southern end rather than in the center of the range and so rejected the model. A question is whether size, growth, and survival data would yield other or contrary results. Intertidal densities and size structures were measured for purple sea urchins along the Pacific coast of North America during 1985-1987 from 29.93 to $50.47^{\circ} \mathrm{N}$, covering about $65 \%$ of the reported geographic range; these historical data were used to explore latitudinal patterns. Recruitment was based on the fractions of individuals in the smallest mode of the size distributions. Growth was determined by tagging with tetracycline and survival was estimated using size distributions and growth. Density of purple sea urchins was highest between 35 and $37^{\circ} \mathrm{N}$ and the samples with the highest numbers of recruits occurred between 34 and $38^{\circ} \mathrm{N}$. Maximum diameter was largest at 43 to $44^{\circ} \mathrm{N}$ and smallest at about $34^{\circ} \mathrm{N}$. There was no latitudinal pattern to growth or survival. Patterns of population traits did not fit simple models or previously published results. The interplay of coastal topography and currents are suggested as the primary determinants of density and recruitment. No general models for describing geographic distributions predict the observed patterns. The southern range limit is best explained by thermal tolerance and the northern limit by development times of larvae at low temperatures.
\end{abstract}

KEY WORDS: Geographic patterns · Demography $\cdot$ Size structure $\cdot$ Growth $\cdot$ Recruitment $\cdot$ Survival $\cdot$ Sea urchin Resale or republication not permitted without written consent of the publisher

\section{INTRODUCTION}

Latitudinal patterns have long been a focus of studies of both theoretical and applied ecology. Across the geographic range of a species there are changes in density that are the result of population processes of growth, survival, reproduction, and recruitment. A common model for density changes is based on Hutchinson's (1957) definition of a niche in which biotic and abiotic factors change in all directions along a gradient from the center of distribution, where conditions are best, out to regions where the species cannot persist. Accordingly, change in density over a species' range is hypothesized to be Gaussian in shape with maximum values in the center of the distribution (e.g. Whittaker 1960, Brown 1984, Guo et al. 2005); this is the abundant center model (e.g. Samis \& Eckert 2007).

Climate change coupled with concerns for species conservation have resulted in increasing interest in species distributions and structure within a variety of systems (e.g. Fortin et al. 2005, Guo et al. 2005, Parmesan et al. 2005, Sagarin et al. 2006, Gaston et al. 2008). For marine systems, recent models have emphasized the role of physical transport in shaping structure (e.g. Richards et al. 1995, Ebert 1996, Alexander \& Roughgarden 1996, Connolly \& Roughgarden 1998, Gaylord \& Gaines 2000), but transport alone cannot explain range limits. At a meso-scale, however, physical trans- 
port clearly influences pattern (e.g. Ebert \& Russell 1988) and is important in understanding changes in distribution or population structure associated with prominent coastal features (e.g. Wares et al. 2001, Zacherl et al. 2003, Herbert et al. 2009, Kelly \& Palumbi 2010).

Lewis (1986) developed a model for the geographic distributions of marine species with planktonic larvae that retains physiological elements of a Hutchinsonian niche and focuses on northern range limits set by short breeding seasons that lead to frequent recruitment failures. Reproductive seasons are longer in the south but thermal stress increases mortality. At both extremes temperature sets limits, and has been considered as the driving force for latitudinal changes by others (e.g. Bullock 1955, Frank 1975, Lonsdale \& Levinton 1985, Harrington 1987, Defeo \& Cardoso 2002).

Several recent papers have tested Brown's model (Brown 1984) of the abundant or domed center for distributions of intertidal species and have failed to support the model. For example, an intertidal limpet failed to show a decline in density and size at the northern edge of its range (Gilman 2005). Sagarin \& Gaines (2002) estimated density of 12 intertidal invertebrate species in transects at 42 sites along the Pacific coast of North America from Punta Cabeza Ballena, Baja California Sur $\left(22.92^{\circ} \mathrm{N}\right)$ to Shelikof Island, Alaska $\left(57.15^{\circ} \mathrm{N}\right)$. They found Strongylocentrotus purpuratus from Punta Baja $\left(29.94^{\circ} \mathrm{N}\right)$ to Boiler Bay, Oregon $\left(44.83^{\circ} \mathrm{N}\right)$. Lester et al. (2007) documented differences in reproduction of $S$. purpuratus from Punta San Carlos, Baja California Norte $\left(29.62^{\circ} \mathrm{N}\right)$ to the Bodega Marine Reserve, California $\left(38.32^{\circ} \mathrm{N}\right)$. Results from these 2 studies failed to support a model with low density or gonad size towards margins and increases towards the center. In both of these studies, the trend was for density and gonad size to increase toward the south end of the range. An older study of gonad development in S. purpuratus from 1958 to 1961 (Boolootian 1966), although complicated by the use of a gonad index, showed greatest gonad development in the north at Sunset Bay, Oregon, through Pacific Grove, California, and lower gonad index values in Mexico. These results are opposite to the results presented by Lester et al. (2007).

To understand population structure over a wide latitudinal range, the best approach is to explore patterns of density, recruitment, size structure, growth, and survival. There are few studies of intertidal populations that span substantial portions of the known range and also include demographic data; therefore, it is reasonable to ask whether, in general, patterns support the abundant center model, a physical transport model (e.g. Ebert 1996, Gaylord \& Gaines 2000), the recruitment-survival model of Lewis (1986), or whether pat- terns are sufficiently species-specific and idiosyncratic that a general model may not be attainable.

The lack of previous publication of the historical data presented here has been associated with problems of analyzing growth of sea urchins. When growth data were gathered in the 1980s, the preferred growth model was the Richards function (Richards 1959, Ebert 1982, Russell 1987). The overall fit of data to this model, however, was not good for small or very large purple sea urchins. The Tanaka growth model (Tanaka 1982 , 1988) was much better for growth analysis of sea urchins (e.g. Ebert \& Russell 1993); however, the model had an implied time interval, $\Delta t$, between marking and recapture of 1 yr. Mostly this was not a major problem (e.g. Ebert et al. 1999), but purple urchin data sets reported here included time intervals as long as $3 \mathrm{yr}$. Improving the Tanaka model to include different values of $\Delta t$ (Ebert \& Southon 2003, Ebert 2008) left the problem of how to compare growth results because there was no simple summary index. A solution to this final problem with growth analysis is presented here.

\section{MATERIALS AND METHODS}

Strongylocentrotus purpuratus has a reported geographic range from Isla Cedros, Baja California Norte $\left(28^{\circ} \mathrm{N}\right)$ (Clark 1913) to at least Torch Bay, Alaska $\left(58.33^{\circ} \mathrm{N}\right)$ (Duggins 1981). The intertidal distribution is ill-defined but extends at least to Punta San Carlos, Baja California Norte $\left(29.62^{\circ} \mathrm{N}\right)$ (Lester et al. 2007). The report of $S$. purpuratus at the southern end of Bahia Tortugas $\left(27.66^{\circ}\right)$ by Olivares-Bañuelos et al. (2008) possibly is a misidentification because a visit to this site in 2009 found just Echinometra vanbrunti, a more southern species (J. C. Hernández pers. comm.). Although predominately subtidal at Torch Bay, Alaska, Duggins \& Quinn (1975) occasionally found S. purpuratus in the low intertidal Lessoniopsis zone.

During the mid-1980s, intertidal populations of the purple sea urchin were studied from Grant Bay $\left(50.47^{\circ} \mathrm{N}\right)$ at the northern tip of Vancouver Island, Canada, to Punta Baja $\left(29.94^{\circ} \mathrm{N}\right)$, Baja California Norte, México (Fig. 1). This range encompasses about $65 \%$ of the reported distribution. At most sites, pools or channels were located and their dimensions measured. At several sites in southern California where sea urchins occurred under rocks, $1 \mathrm{~m}$ belt transects were run parallel with the shore. Surface area of a pool or channel was estimated based on simple measures of the waterline of the surface and general shape such as rectangle, triangle, oval, etc. Pools and channels varied in depth and so there was additional area provided by the sides and complexity (cracks, pits). This increase in area over the estimate of surface area is a source of 


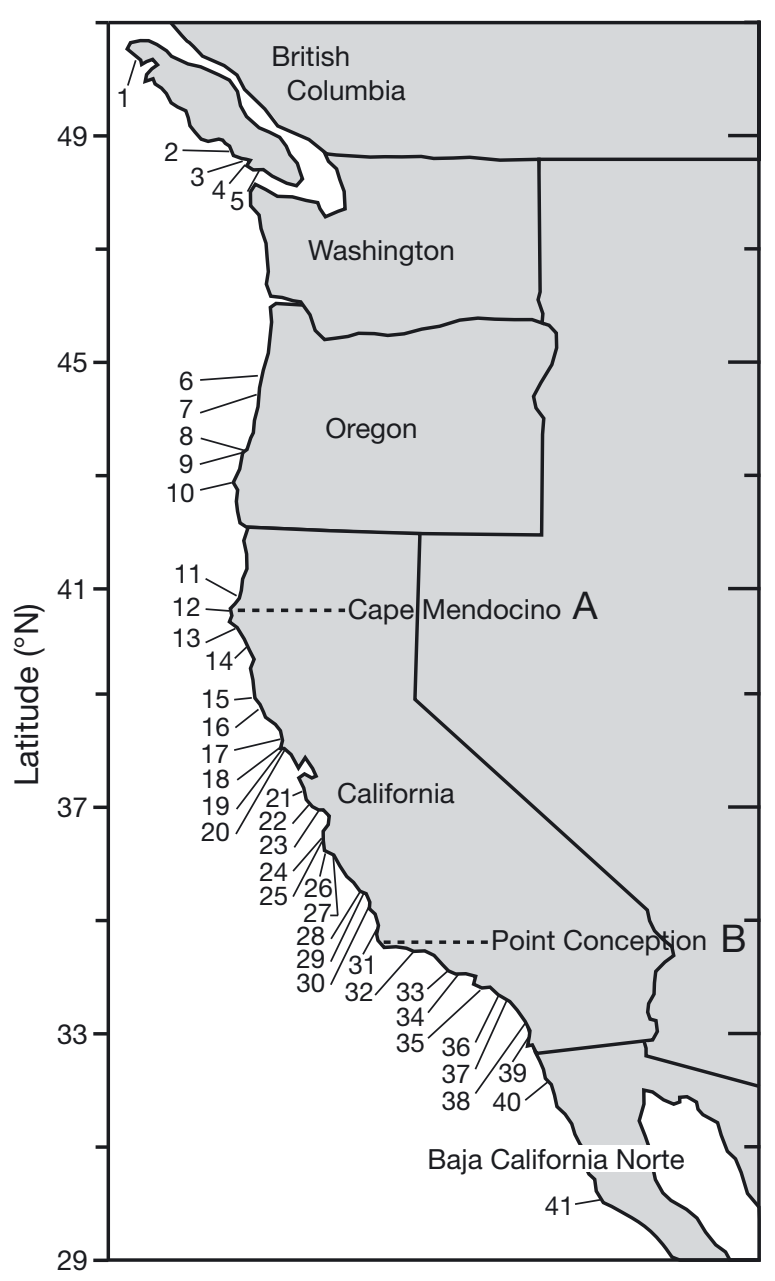

Fig. 1. Strongylocentrotus purpuratus. Study sites along the Pacific coast of North America; details of sites given in Table 1. Dashed lines A and B mark positions of Cape Mendocino and Point Conception and are important markers used in other figures

error, but is the same error used in other studies that have attempted to estimate density of organisms in the intertidal (e.g. Sagarin \& Gaines 2002). Density in pools potentially was overestimated and with greatest error for deep pools with small surface areas; all densities were scaled to a surface area of $1 \mathrm{~m}^{2}$.

At study sites, all sea urchins were collected from a defined area, diameters were measured with vernier calipers to the nearest $0.01 \mathrm{~cm}$, and then urchins were returned. A restriction in sampling was that new individuals had to be large enough to be seen and collected with unaided vision. Although occasionally sea urchins with diameters as small as $0.25 \mathrm{~cm}$ were collected, most of this size would have been missed; the lower limit for collection was about $0.5 \mathrm{~cm}$. Sizefrequency distributions were separated into 2 or more components using the algorithm of Macdonald \& Pitcher
(1979) to determine the fraction of the population that was about 1 yr old.

Size at settlement under laboratory conditions is about 0.03 to $0.04 \mathrm{~cm}$ depending on food conditions (Rowley 1989, Miller \& Emlet 1999) and settlement time varies year to year from as early as March to as late as August (Rowley 1989, Ebert et al. 1994, Miller \& Emlet 1997). At Sunset Bay, Oregon, sea urchins that settled in 1963 in different sites had mean diameters of 1.62 to $1.94 \mathrm{~cm}$ in August 1964 (Ebert 1968). In southern California, Rowley (1989) estimated 1 yr old urchins to be ca. $1.90 \mathrm{~cm}$ in diameter. These approximate values were used as a gauge to evaluate the appropriateness of using fractions of the first mode in size-frequency distributions as Age $\leq 1$, recognizing that the first mode may include some individuals not yet 1 yr old and some older but not equal to $2 \mathrm{yr}$.

At 5 sites along the coast, sea urchins were tagged with tetracycline (Ebert 1982) to determine growth: Maalth-sit $\left(48.72^{\circ} \mathrm{N}\right.$; Site 4 in Fig. 1), Arena Cove $\left(38.92^{\circ} \mathrm{N}_{\text {; }}\right.$ Site 15$)$, Bodega Marine Reserve $\left(38.33^{\circ} \mathrm{N}_{i}\right.$ Site 17), McClure Beach $\left(38.18^{\circ} \mathrm{N}\right.$; Site 18), and Punta Baja $\left(29.93^{\circ} \mathrm{N}\right.$; Site 41$)$. The Maalth-sit site was called Flat Top Rock by Russell (1987). Sea urchins generally were collected after about $1 \mathrm{yr}$, but in one case after $1.5 \mathrm{yr}$ and in another after $3 \mathrm{yr}$ (because the collection was from the wrong pool after $1 \mathrm{yr}$ ), and processed as has been previously described (e.g. Ebert 1982).

Growth increments in demi-pyramids (jaws) of Aristotle's lantern were measured under ultraviolet illumination and converted to growth in body (test) diameter after determining the site-specific allometric relationship between test diameter $(D)$ and jaw length $(J)$ :

$$
D=\alpha J^{\beta}
$$

Data were transformed for analysis using natural logarithms:

$$
\ln D=A+\beta \ln J
$$

where $A$ is $\ln \alpha$.

The jaw size at the time of tagging, $J_{t}$, is the size at subsequent collection, $J_{t+\Delta t}$, minus the jaw increment, $\Delta J$, which is the sum of the growth increments at the esophageal and labial ends of the jaw. Allometry parameters were used for each sample to estimate the growth increment of the test, $\Delta D$ :

$$
\Delta D=\alpha\left(J_{t+\Delta t}^{\beta}-J_{t}^{\beta}\right)
$$

Two growth models were used for analysis, Tanaka (Tanaka 1982) and Richards (Richards 1959). The Tanaka equation is:

$$
\Delta D=-D_{t}+\frac{1}{\sqrt{f}} \ln \left[2 G+2 \sqrt{G^{2}+f a}\right]+d
$$


where

$$
\begin{aligned}
& G=E / 4-f a / E+f \Delta t \\
& E=\exp \left[\sqrt{f}\left(D_{t}-d\right)\right]
\end{aligned}
$$

$\Delta t$ is the time interval between tagging and collection and $a, d$ and $f$ are parameters to be estimated. Further details of the Tanaka equation are given in Tanaka (1988) and Ebert (1999).

The Richards equation is:

$$
\Delta D=-D_{t}+\left[D_{t}^{-1 / n}+\left(D_{\infty}^{-1 / n}-D_{t}^{-1 / n}\right)\left(1-\mathrm{e}^{-K \Delta t}\right)\right]^{-n}
$$

Comparisons of samples were made by estimating $\Delta D$ at an initial diameter of $3 \mathrm{~cm}$ and $\Delta t$ equal to $1 \mathrm{yr}$. An initial size of $3 \mathrm{~cm}$ was selected because it was well within the data clouds of all samples. This is an approach similar to that advocated by Schnute (1981) and implemented in difference-equation form by Francis (1995). Growth parameters were estimated using the nonlinear regression module NONLIN (SYSTAT 2004) and included the function command (FUNPAR) to estimate $\Delta D$ at $3 \mathrm{~cm}$ together with $95 \%$ confidence limits.

Survival was modeled using an exponential equation:

$$
N_{t}=N_{0} \mathrm{e}^{-M t}
$$

which assumed that the annual survival rate did not change with age. The parameter $M$ is the instantaneous survival rate and the annual survival rate $P^{-1}$, is $\mathrm{e}^{-M}$. The estimate of $M$ was obtained using the mean diameter of the size-frequency data, $D_{\mathrm{T}}$, and the Tanaka growth parameters (Eq. 7) that were obtained from tagging (Ebert 1999):

$$
\begin{aligned}
& \overline{D_{T}}=\left(1-\mathrm{e}^{-M}\right) \\
& \left(\sum_{t=0}^{\infty} \mathrm{e}^{-M t}\left[\frac{1}{\sqrt{f}} \ln \left(2 f((t+T)-c)+2 \sqrt{f^{2}((t+T)-c)^{2}+f a}\right)+d\right]\right)
\end{aligned}
$$

In Eq. (7), the Tanaka growth function (in square brackets) has an additional parameter, $T$, which is the time of year since annual recruitment. It can be set equal to 0 if the mean of the smallest mode in a size distribution is selected as the size at recruitment, $D_{0}$. The mean diameter of Age $\leq 1$ individuals, $D_{0}$, enters Eq. (7) through $c$ :

$$
\begin{gathered}
E=\exp \left[\sqrt{f}\left(D_{0}-d\right)\right] \\
C=\frac{a}{E}-\frac{E}{4 f}
\end{gathered}
$$

The only unknown in Eq. (7) is $M$, the instantaneous mortality rate, which was estimated using a numerical algorithm called Newton's method. Finding a solution for $M$ starts with a seed value for $M$ such as 1.0 or 0.5 and iterates to improve the estimate until the estimate of $M$ for the $i$ th +1 iteration is no more than $1 \times 10^{-6}$ different from the $i$ th iteration. A BASIC program for solving Eq. (7) by Newton's method is in Ebert (1999). Assumptions in application of Eq. (7) are that Eq. (6) is valid and that the population is seasonally stable and stationary; that is, the population has fixed fractions in each size category if sampling is always done at the same time of year (seasonally stable) and the population is neither growing nor declining (seasonally stationary).

\section{RESULTS \\ Density}

The pattern of density with latitude (Fig. 2) showed the highest values between 35 and $37^{\circ} \mathrm{N}$, which is north from Point Conception to about Bean Hollow

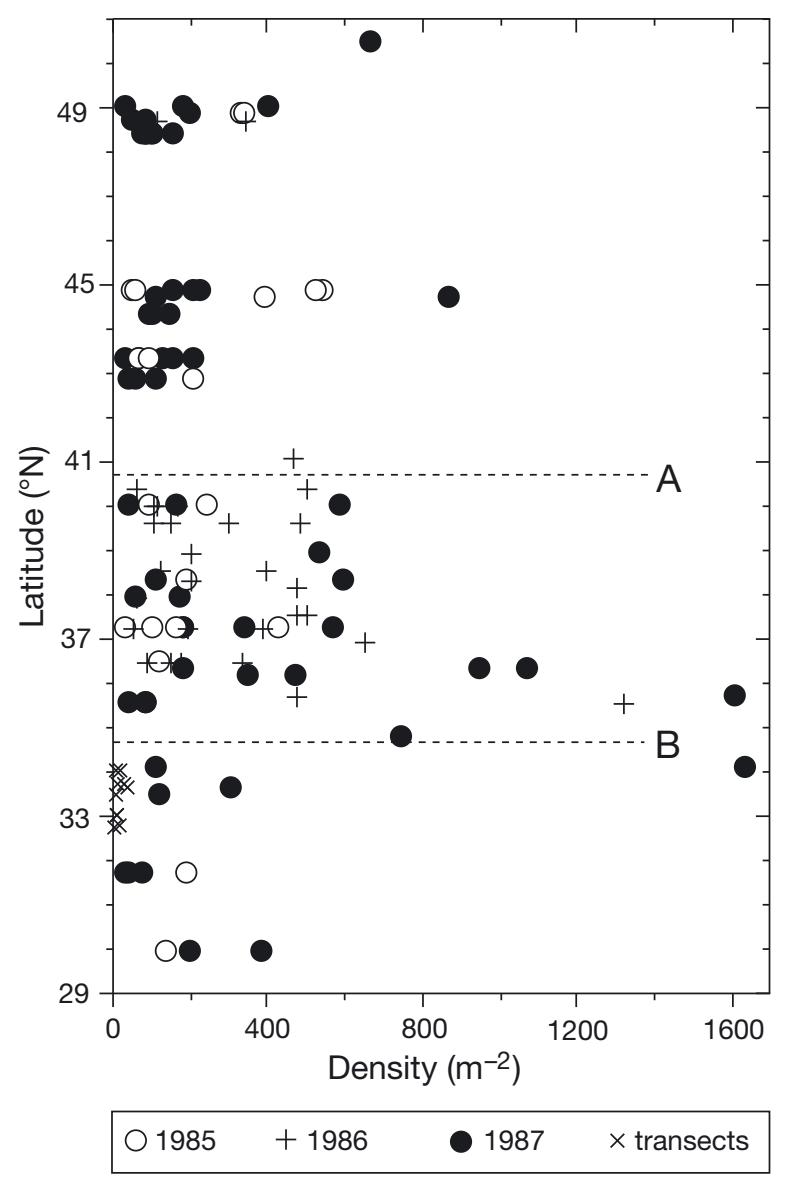

Fig. 2. Strongylocentrotus purpuratus. Density as a function of latitude along the Pacific coast of North America. Densities were calculated based on surface area of pools or crevices and then adjusted to a standard $\mathrm{m}^{-2}$; transects were used at cobble beaches. Dashed lines A and B are Cape Mendocino and Point Conception, respectively 
(Site 22 in Fig. 1) in central California. Density then declined to low values in Oregon from Cape Blanco (Site 10) to Yaquina Head (Site 7) followed by an increase farther north. At all latitudes there were samples with low densities, which indicates that sites were sampled of varying quality for recruitment, postsettlement survival, or a combination of the two. The low densities in transects in southern California are a reflection of variable micro-site quality on beaches with cobbles and rock slabs interspersed with smaller rocks resting on variable amounts of gravel and sand. The highest density estimates of $1600 \mathrm{~m}^{-2}$ were from Piedras Blancas (Site 28) and Leo Carillo State Park (Site 33), both in 1987. At Piedras Blancas on 27 March 1987, 1286 sea urchins were collected in a shallow pool that had an estimated surface area of $0.80 \mathrm{~m}^{2}$. Most of these sea urchins were very small and mean diameter was just $1.98 \mathrm{~cm}$. In contrast, at Leo Carillo State Park only 193 sea urchins were collected in a small pool that had an estimated surface area of just $0.12 \mathrm{~m}^{2}$. Sea urchins were larger than at Peidras Blancas and mean diameter was $2.53 \mathrm{~cm}$. The estimate of bottom area based on surface area for the Leo Carillo pool probably contains more error than the estimate of bottom area at Piedras Blancas, but the actual error is unknown.

\section{Fraction of Age $\leq 1 \mathrm{yr}$}

Data of total numbers collected $(\mathrm{N})$, dates, and the fraction in the Age $\leq 1$ class are provided in Table 1. Representative size-frequency distributions (Fig. 3) show initial modes of about $1.5 \mathrm{~cm}$, and these would consist of Age $\leq 1$ sea urchins. There is clean separation of modes in the samples from Punta Baja (Site 41) and Arena Cove (Site 15) in 1987, but less clear separation at Piedras Blancas (Site 28) and McClure Beach (Site 18). Very few new recruits were observed in the Boulder Field at Sunset Bay (Site 8), Oregon, and there were no recruits at Grant Bay (Site 1) at the north end of Vancouver Island, British Columbia, evident in 1987.

Plotting the Age $\leq 1$ data of Table 1 (Fig. 4) shows peak recruitment between 35 and $39^{\circ} \mathrm{N}$, a low in Oregon, and a rise on Vancouver Island. The fraction of Age $\leq 1$ individuals showed a pattern similar to that of density with a peak in central California, a minimum in Oregon, and intermediate values in both Canada and México. Similarly, there were sites all along the coast with low values for recruitment and a clear indication of annual variation. Samples in central California showed high recruitment in 1987, an indication of high settlement in 1986. The lowest

Table 1. Strongylocentrotus purpuratus study sites 1985-1987; site numbers are mapped in Fig. 1. North latitude is expressed with decimal degrees rather than with minutes. Samples include size (N) and Age $\leq 1$ fraction of the distributions. SP: state park

\begin{tabular}{|c|c|c|c|c|c|c|c|c|c|c|c|}
\hline \multirow[t]{2}{*}{ No. } & \multirow[t]{2}{*}{ Site } & \multirow{2}{*}{$\begin{array}{c}\text { Latitude } \\
\left({ }^{\circ} \mathrm{N}\right)\end{array}$} & \multirow[t]{2}{*}{ Date } & \multicolumn{2}{|c|}{ Sample 1} & \multicolumn{2}{|c|}{ Sample 2} & \multicolumn{2}{|c|}{ Sample 3} & \multicolumn{2}{|c|}{ Sample 4} \\
\hline & & & & $\mathrm{N}$ & Age $\leq 1$ & $\mathrm{~N}$ & Age $\leq 1$ & $\mathrm{~N}$ & Age $\leq 1$ & $\mathrm{~N}$ & Age $\leq 1$ \\
\hline 1 & Grant Bay & 50.47 & 29-Apr-87 & 215 & 0 & & & & & & \\
\hline 2 & Frank Island & 49.02 & 28-Apr-87 & 63 & 0 & 72 & 0.014 & 284 & 0.01 & & \\
\hline 3 & Seppings Island & 48.83 & 2-Aug-85 & 233 & 0.285 & 292 & 0.273 & & & & \\
\hline \multirow[t]{4}{*}{4} & Maalth-sit & 48.72 & 1-Aug-85 & 372 & 0.107 & 264 & 0.03 & & & & \\
\hline & & & 13-Nov-85 & 116 & 0 & & & & & & \\
\hline & & & 25-Apr-86 & 76 & 0 & 185 & 0 & 194 & 0.005 & & \\
\hline & & & $26-A p r-87$ & 64 & 0.016 & 149 & 0.007 & 241 & 0 & & \\
\hline 5 & Botanical Beach & 48.38 & 31-Jul-85 & 557 & 0.072 & & & & & & \\
\hline \multirow[t]{2}{*}{6} & Boiler Bay & 44.83 & 7-Jun-85 & 175 & 0.069 & 233 & 0.069 & 86 & 0.093 & 55 & 0.054 \\
\hline & & & 18-May-87 & 273 & 0.026 & 122 & 0.016 & 206 & 0.015 & & \\
\hline \multirow[t]{2}{*}{7} & Yaquina Head & 44.68 & 6-Jun-85 & 646 & 0.147 & & & & & & \\
\hline & & & 17-May-87 & 506 & 0.109 & 170 & 0.196 & & & & \\
\hline \multirow[t]{13}{*}{8} & Sunset Bay & 43.33 & & & & & & & & & \\
\hline & Postelsia zone (PZ) & & 5-Jun-85 & 214 & 0.014 & & & & & & \\
\hline & Above PZ & & 5-Jun-85 & 87 & 0.011 & & & & & & \\
\hline & Below PZ and N & & 5-Jun-85 & 208 & 0.091 & & & & & & \\
\hline & Boulder field & & 5-Jun-85 & 57 & 0 & 340 & 0.026 & & & & \\
\hline & Surf grass area & & 5-Jun-85 & 203 & 0.034 & & & & & & \\
\hline & Below PZ and N & & 15-May-87 & 182 & 0.016 & & & & & & \\
\hline & Below PZ and S & & 15-May-87 & 180 & 0.038 & & & & & & \\
\hline & Postelsia zone & & 15-May-87 & 206 & 0.015 & & & & & & \\
\hline & Above PZ & & 16-May-87 & 49 & 0.02 & & & & & & \\
\hline & Boulder field & & 16-May-87 & 234 & 0.051 & & & & & & \\
\hline & Surf grass area & & 16-May-87 & 192 & 0.01 & & & & & & \\
\hline & South of boulder field & & 16-May-87 & 68 & 0 & & & & & & \\
\hline 9 & Cape Arago & 43.31 & 9-Jun-85 & 109 & 0.009 & 131 & 0 & & & & \\
\hline
\end{tabular}


Table 1 (continued)

\begin{tabular}{|c|c|c|c|c|c|c|c|c|c|c|c|}
\hline \multirow[t]{2}{*}{ No. } & \multirow[t]{2}{*}{ Site } & \multirow{2}{*}{$\begin{array}{l}\text { Latitude } \\
\qquad\left({ }^{\circ} \mathrm{N}\right)\end{array}$} & \multirow[t]{2}{*}{ Date } & \multicolumn{2}{|c|}{ Sample 1} & \multicolumn{2}{|c|}{ Sample 2} & \multicolumn{2}{|c|}{ Sample 3} & \multicolumn{2}{|c|}{ Sample 4} \\
\hline & & & & $\mathrm{N}$ & Age $\leq 1$ & $\mathrm{~N}$ & Age $\leq 1$ & $\mathrm{~N}$ & Age $\leq 1$ & $\mathrm{~N}$ & Age $\leq 1$ \\
\hline \multirow[t]{2}{*}{10} & Cape Blanco & 42.84 & 4-Jun-85 & 472 & 0.025 & & & & & & \\
\hline & & & 14-May-87 & 214 & 0.014 & 133 & 0.023 & 92 & 0.033 & & \\
\hline 11 & Elk Head & 41.07 & 27-May-86 & 372 & 0.121 & & & & & & \\
\hline 12 & Devil's Gate & 40.4 & 26-May-86 & 30 & 0 & 200 & 0.035 & 100 & 0.03 & & \\
\hline \multirow[t]{3}{*}{13} & Shelter Cove & 40.03 & 3-Jun-85 & 322 & 0.05 & 176 & 0.045 & & & & \\
\hline & & & 25-May-86 & 94 & 0.074 & 151 & 0.113 & 194 & 0.036 & & \\
\hline & & & 13-May-87 & 129 & 0.217 & 58 & 0.241 & 73 & 0.26 & & \\
\hline 14 & Bruhl Point & 39.6 & 28-May-86 & 103 & 0.126 & 163 & 0.395 & 151 & 0.222 & 269 & 0.264 \\
\hline \multirow[t]{4}{*}{15} & Arena Cove & 38.92 & 14-Apr-85 & 280 & 0.004 & & & & & & \\
\hline & & & 2-Jun-85 & 50 & 0.02 & & & & & & \\
\hline & & & 29-Apr-86 & 270 & 0 & & & & & & \\
\hline & & & 1-May-87 & 242 & 0.24 & 216 & 0.268 & & & & \\
\hline 16 & Windermere Point & 38.53 & 29-May-86 & 378 & 0.305 & 371 & 0.148 & & & & \\
\hline \multirow[t]{3}{*}{17} & Bodega Marine & 38.33 & 13-Apr-85 & 405 & 0.204 & & & & & & \\
\hline & Reserve & & 28-Apr-86 & 331 & 0.203 & & & & & & \\
\hline & & & 30-Apr-87 & 74 & 0.257 & 390 & 0.583 & & & & \\
\hline 18 & McClure Beach & 38.18 & 30-May-86 & 217 & 0.859 & & & & & & \\
\hline \multirow[t]{2}{*}{19} & Palomarin Beach & 37.95 & 24-May-86 & 241 & 0.004 & 177 & 0 & & & & \\
\hline & & & 3-May-87 & 126 & 0.016 & 207 & 0.092 & & & & \\
\hline 20 & Duxbury Reef & 37.88 & 2-Jun-85 & 107 & 0.019 & 316 & 0.071 & & & & \\
\hline 21 & $\begin{array}{l}\text { Fitzgerald Marine } \\
\text { Reserve }\end{array}$ & 37.53 & 23-May-86 & 142 & 0.021 & 240 & 0 & & & & \\
\hline \multirow[t]{3}{*}{22} & Bean Hollow & 37.22 & 1-Jun-85 & 65 & 0.062 & 33 & 0.091 & 88 & 0.136 & 120 & 0.447 \\
\hline & & & 22-May-86 & 95 & 0.039 & 58 & 0.086 & 192 & 0.223 & & \\
\hline & & & 12-May-87 & 130 & 0.507 & 118 & 0.327 & 46 & 0.413 & & \\
\hline 23 & Natural Bridges & 36.95 & $17-O c t-86$ & 488 & 0.336 & & & & & & \\
\hline \multirow[t]{2}{*}{24} & Garrapata SP & 36.47 & 1-Jun-85 & 333 & 0.069 & & & & & & \\
\hline & & & 22-May-86 & 160 & 0.156 & 229 & 0.109 & & & & \\
\hline 25 & Soberanes Point & 36.45 & 22-Jun-86 & 62 & 0.113 & 81 & 0.025 & 456 & 0.363 & & \\
\hline 26 & Andrew Molera SP & 36.28 & 26-Mar-87 & 183 & 0.651 & 101 & 0.521 & 333 & 0.686 & & \\
\hline 27 & Partington Cove & 36.17 & 25-Mar-87 & 81 & 0.463 & 234 & 0.59 & & & & \\
\hline \multirow[t]{2}{*}{28} & Piedras Blancas site \#1 & 135.68 & 23-Jun-86 & 167 & 0.042 & & & & & & \\
\hline & Piedras Blancas site \#2 & $2 \quad 35.66$ & 27-Mar-87 & 1286 & 0.684 & & & & & & \\
\hline \multirow[t]{2}{*}{29} & Cambria & 35.54 & 23-Jun-86 & 291 & 0.217 & & & & & & \\
\hline & & & 28-Mar-87 & 232 & 0.392 & 119 & 0.302 & 128 & 0.193 & & \\
\hline 30 & Montana de Oro SP & 35.27 & 4-Jul-85 & 40 & 0 & 176 & 0.095 & & & & \\
\hline 31 & Purisima Point & 34.76 & 26-Jan-87 & 80 & 0.605 & & & & & & \\
\hline 32 & Coal Oil Point & 34.47 & 5-Jul-85 & 102 & 0.336 & & & & & & \\
\hline 33 & Leo Carillo SP & 34.04 & 27-Jan-87 & 193 & 0.359 & 413 & 0.189 & & & & \\
\hline 34 & Paradise Cove & 34.01 & 25-Jan-87 & 169 & 0.388 & 51 & 0.381 & & & & \\
\hline \multirow[t]{2}{*}{35} & White Point & 33.71 & 3-Jul-85 & 195 & 0.005 & & & & & & \\
\hline & & & 12-Jan-87 & 176 & 0.626 & 179 & 0.557 & & & & \\
\hline 36 & Pelican Point & 33.58 & 10-Jan-87 & 248 & 0.27 & 147 & 0.088 & & & & \\
\hline 37 & Dana Point & 33.45 & 11-Jan-87 & 63 & 0.105 & 140 & 0.231 & & & & \\
\hline 38 & Encinitas & 33.03 & 28-Jan-87 & 112 & 0.696 & & & & & & \\
\hline 39 & False Point & 32.8 & 14-Jan-87 & 74 & 0.176 & & & & & & \\
\hline 40 & S of Papalote Bay & 31.71 & 2-Jul-85 & 332 & 0.015 & & & & & & \\
\hline & & & 11-Mar-87 & 447 & 0.129 & 224 & 0.04 & 44 & 0.091 & & \\
\hline 41 & Punta Baja & 29.94 & 1-May-85 & 212 & 0.009 & & & & & & \\
\hline & & & 12-Mar-87 & 680 & 0.418 & 195 & 0.249 & & & & \\
\hline
\end{tabular}

recruitment in central California occurred in 1985, meaning poor settlement in 1984. Recruitment in Canada showed a pattern opposite to California, i.e. settlement in 1984 was good as shown by the recruitment of Age $\leq 1$ sea urchins in 1985. Settlement in 1986 was poor as shown by poor recruitment in 1987 .

\section{Changes in maximum test diameter with latitude}

Maximum diameter, the largest measured sea urchin in a sample, provides additional insight into pattern with latitude. Maximum measured diameter is a better measure than mean or mode because it is not influenced by differences in recruitment events. Maximum 

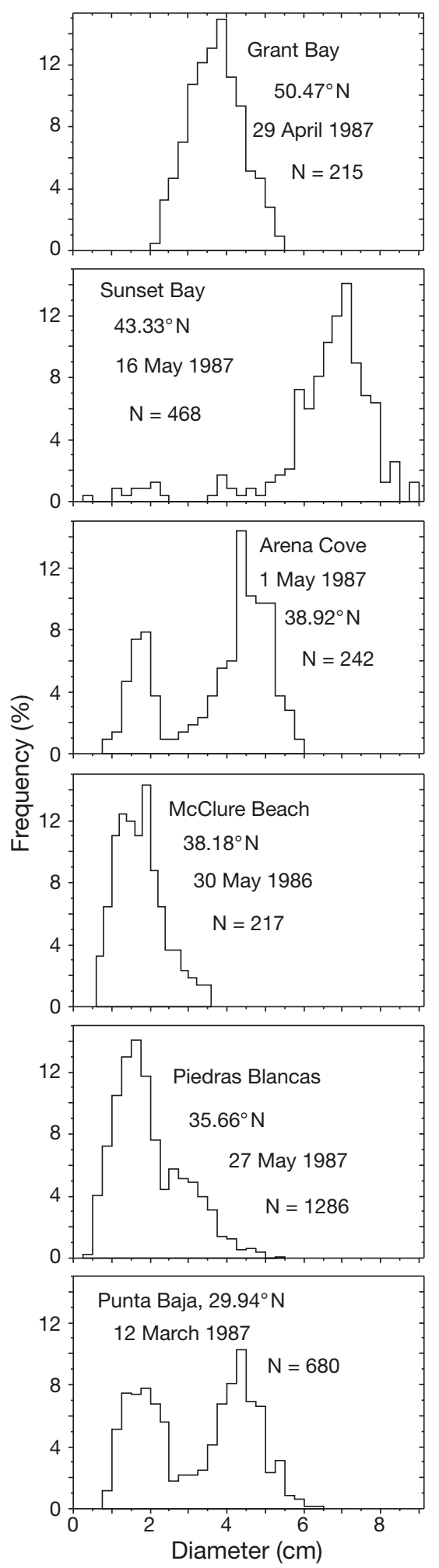

Fig. 3. Strongylocentrotus purpuratus. Representative size structures arranged from north to south to illustrate fractions present in the smallest size class, which is approximately Age $\leq 1$ : Grant Bay (Site 1, Fig. 1), Sunset Bay (Site 8), Arena Cove (Site 15), McClure Beach (Site 18), Piedras Blancas (Site 28), and Punta Baja (Site 41)

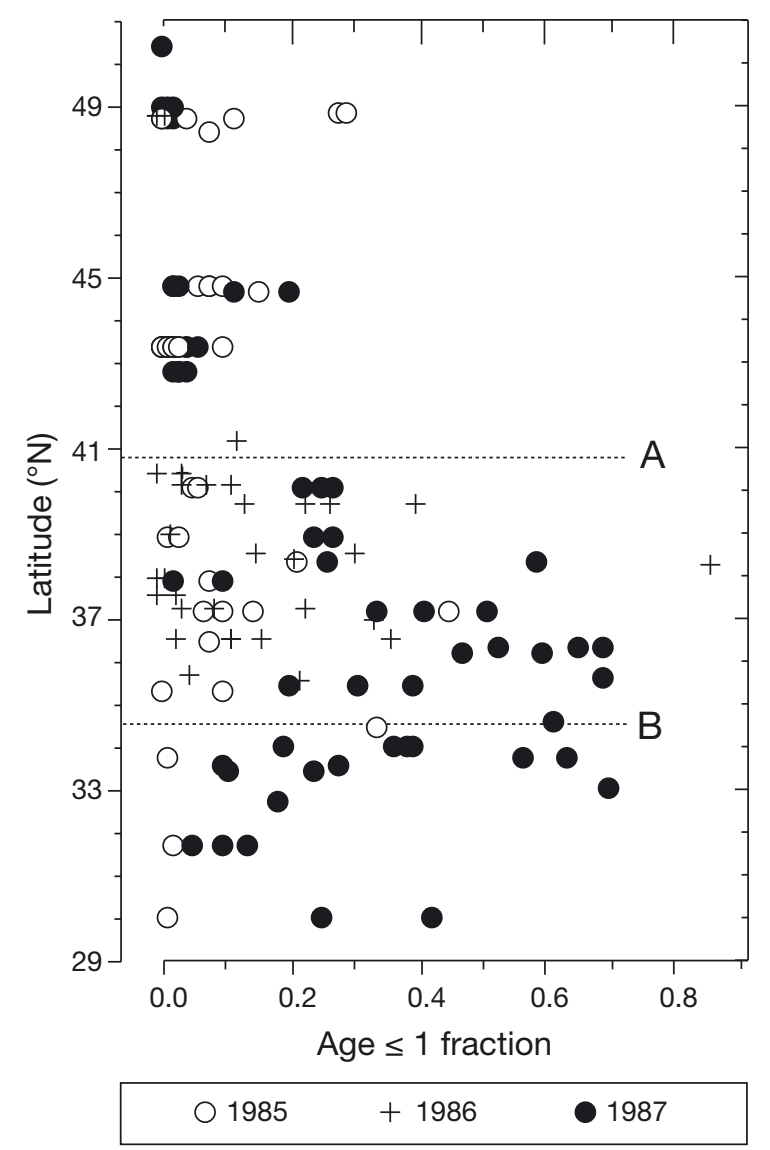

Fig. 4. Strongylocentrotus purpuratus. Fraction of Age $\leq 1$ individuals in size distributions along the Pacific coast of North America. Dashed lines A and B are Cape Mendocino and Point Conception, respectively

observed diameter (Fig. 5) changed with latitude first with a drop at Point Conception followed by a steady rise past Cape Mendocino and attaining largest individuals in Oregon from Cape Blanco (Site 10) to Yaquina Head (Site 7). This was followed by a drop in maximum diameter on Vancouver Island. The greatest inter-sample variation occurred at about $38^{\circ} \mathrm{N}$, with large individuals over $8.0 \mathrm{~cm}$ at Palomarin Beach $\left(37.95^{\circ} \mathrm{N}\right.$, Site 19$)$ and, close by, very small sea urchins a McClure Beach $\left(38.18^{\circ} \mathrm{N}\right.$, Site 18$)$. It is important to note that there were areas, such as along the Oregon coast, where no sites were sampled where maximum sizes were less than $6.0 \mathrm{~cm}$.

\section{Growth}

Examination of growth across latitude provides a clear test of the abundant center model. Expectation is that growth should be highest in the middle of the range and lowest at the northern and southern ends of 


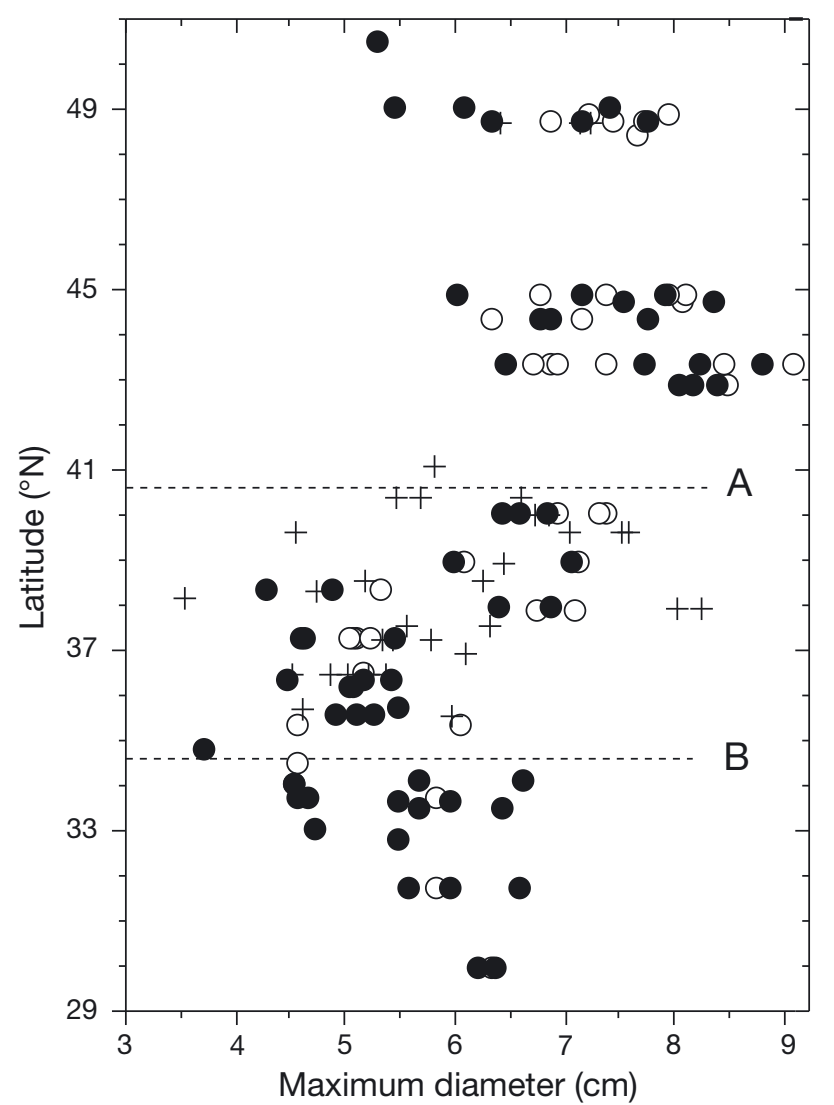

\begin{tabular}{|lll|}
\hline$\bigcirc 1985$ & $+1986 \quad \bigcirc 1987$ \\
\hline
\end{tabular}

Fig. 5. Strongylocentrotus purpuratus. Maximum diameter in samples measured along the Pacific coast of North America. Dashed lines A and B are Cape Mendocino and Point Conception, respectively

Growth parameters of the Tanaka function were determined (Eq. 4) for each sample. The correlation between parameters $f$ and $d$ ranged from 0.390 to 0.997 with a weighted mean of 0.91 . Also, the $95 \%$ confidence intervals of $f$ overlapped for all samples, which suggested that $f$ could be fixed and estimation reduced to just 2 parameters. The weighted mean value for $f$ was 1.3 and analyses were redone for each sample (NONLIN; SYSTAT 2004), testing the null hypothesis that there was no difference in fit between estimating 3 parameters, $f, a$, and $d$, and fixing $f$ at 1.3 and estimating just 2 parameters. No p-value was $<0.05$ and all but one was $>0.10$ (Table 3 ), so fixing $f$ to reduce the number of fitted parameters is reasonable.

Parameters $n, k$, and $D_{\infty}$ of the Richards function (Eq. 5) were estimated for all samples. Correlation of parameters and 95\% confidence intervals were examined to see whether parameter number could be re- the range. To convert jaw growth to test growth, the first test was whether common allometry parameters could be used for all sites. Jaw lengths, $J$, and test diameters, $D$, were transformed using natural logarithms (Eq. 2) and then used in an ANCOVA (GLM; SYSTAT 2004) with $\ln D$ as the dependent variable, Sample as a grouping variable, $\ln J$ as a covariate, and an interaction term of Sample $\times \ln J$ (Table 2A). The interaction term indicated that slopes were not homogeneous $\left(F_{12,2243}=6.129, \mathrm{p}<\right.$ 0.0001). Accordingly, individual regressions were determined for each sample (Table 2B) and the parameters $\alpha$ and $\beta$ were used to convert jaw growth to diameter growth, $\Delta D$ (Eq. 3). Numbers associated with Maalth-sit are pools where urchins were collected so 2_85 is Pool 2 collected in 1985 and where urchins had been tagged in 1984. Maalth-sit W_85 was collected in 1985 as Pool 1 but was the wrong pool. Pool 1 where urchins had been tagged in 1984 was collected in 1987 and called Pool 4_87 because there were 3 pools that had been tagged in 1986 (Tables 2 to 4 and Figs. 6 \& 7).
Table 2. Strongylocentrotus purpuratus. Allometric parameters for ln diameter $(\ln D)$ as a function of $\ln$ jaw length $(\ln J)$. (A) ANOVA with $\ln D$ as the dependent variable and an interaction term of Sample $\times \ln J$ to determine homogeneity of slopes. (B) Individual regression parameters for sites estimated because the interaction term in (A) was significant at $\mathrm{p}<0.0001$

\begin{tabular}{|c|c|c|c|c|c|c|}
\hline $\begin{array}{l}\text { A. ANOVA } \\
\text { Source }\end{array}$ & $\mathrm{SS}$ & & df & MS & $F$ & $\mathrm{p}$ \\
\hline $\ln J$ & 41.817 & & 1 & 41.817 & 12363.4 & 0.000 \\
\hline Sample & 1.407 & & 12 & 0.117 & 34.662 & 0.000 \\
\hline Sample $\times \ln J$ & 0.249 & & 12 & 0.021 & 6.129 & 0.000 \\
\hline Error & 7.587 & & 243 & 0.003 & & \\
\hline \multicolumn{7}{|c|}{$\begin{array}{l}\text { B. Allometric parameters with } \mathbf{9 5} \% \text { CI for individual samples } \\
\text { (arranged from north to south) }\end{array}$} \\
\hline Sample & Date & $\mathrm{N}$ & $\ln (\alpha)$ & $95 \% \mathrm{CI}$ & $\beta$ & $95 \%$ CI \\
\hline Maalth-sit 2_85 & 13-Nov-85 & 54 & 1.492 & $1.473-1.510$ & 1.167 & $1.118-1.217$ \\
\hline Maalth-sit 3_85 & 13-Nov-85 & 17 & 1.478 & $1.458-1.498$ & 0.949 & $0.838-1.059$ \\
\hline Maalth-sit W_85 & 13-Nov-85 & 202 & 1.476 & $1.467-1.484$ & 1.075 & $1.039-1.111$ \\
\hline Maalth-sit 1_87 & 26-Apr-87 & 62 & 1.485 & $1.469-1.500$ & 1.103 & $1.031-1.175$ \\
\hline Maalth-sit 2_87 & 26-Apr-87 & 145 & 1.455 & $1.445-1.466$ & 1.102 & $1.042-1.161$ \\
\hline Maalth-sit 3_87 & 27-Apr-87 & 239 & 1.507 & $1.500-1.514$ & 1.193 & $1.159-1.227$ \\
\hline Maalth-sit 4_87 & 5-Nov-87 & 189 & 1.469 & $1.461-1.476$ & 1.105 & $1.069-1.141$ \\
\hline Arena 86 & 29-Apr-86 & 217 & 1.502 & $1.493-1.511$ & 1.113 & $1.053-1.173$ \\
\hline Arena 87 & 1-May-87 & 176 & 1.469 & $1.458-1.480$ & 1.107 & $1.075-1.139$ \\
\hline Bodega 85 & 13-Apr-85 & 123 & 1.476 & $1.458-1.494$ & 1.124 & $1.085-1.163$ \\
\hline Bodega 86 & 26-Apr-86 & 340 & 1.473 & $1.464-1.482$ & 1.134 & $1.114-1.154$ \\
\hline McClure & 2-Мау-87 & 105 & 1.596 & $1.572-1.619$ & 1.210 & $1.185-1.234$ \\
\hline Punta Baja 85 & 10-Oct-85 & 400 & 1.540 & $1.534-1.547$ & 1.042 & 0.996-1.088 \\
\hline
\end{tabular}


Table 3. Strongylocentrotus purpuratus. Tanaka parameters $d$ and a with parameter $f$ fixed at 1.30 . The p-value is the probability that the fit with $f$ fixed at 1.30 does not differ from the fit when $f, d$, and $a$ all were estimated. Degrees of freedom for all tests is $\mathrm{N}-3$. The conclusion is that fixing $f$ at 1.30 is justified for all samples at $\alpha=0.05$

\begin{tabular}{|c|c|c|c|c|c|c|c|}
\hline Sample & $\mathrm{N}$ & $d$ & $95 \% \mathrm{CI}$ & $a$ & $95 \% \mathrm{CI}$ & $F$ & $\mathrm{p}$ \\
\hline Maalth-sit 285 & 43 & 1.859 & $1.544-2.175$ & 2.737 & $2.014-3.461$ & 0.148 & 0.70 \\
\hline Maalth-sit 385 & 15 & 1.817 & $1.470-2.164$ & 1.214 & $-0.045-2.474$ & 0.866 & 0.37 \\
\hline Maalth-sit 187 & 55 & 1.960 & $1.775-2.145$ & 1.320 & $0.810-1.830$ & 1.251 & 0.27 \\
\hline Maalth-sit 287 & 140 & 1.522 & $1.396-1.648$ & 1.735 & $0.891-2.579$ & 2.336 & 0.13 \\
\hline Maalth-sit 387 & 35 & 2.355 & $2.175-2.535$ & 3.741 & $2.874-4.609$ & 0.713 & 0.41 \\
\hline Maalth-sit 487 & 129 & 1.441 & $1.322-1.561$ & 2.470 & $1.347-3.594$ & 0.163 & 0.69 \\
\hline Arena 86 & 182 & 1.701 & $1.585-1.818$ & 1.190 & $0.586-1.793$ & 2.666 & 0.10 \\
\hline Arena 87 & 137 & 1.595 & $1.451-1.738$ & 0.294 & $-0.893-1.482$ & 3.139 & 0.08 \\
\hline Bodega 85 & 13 & 0.951 & $0.256-1.647$ & -0.739 & $-8.915-7.436$ & 1.143 & 0.31 \\
\hline Bodega 86 & 141 & 1.432 & $1.339-1.524$ & 0.558 & $0.470-0.647$ & 1.661 & 0.20 \\
\hline McClure & 22 & 0.667 & $0.315-1.018$ & 1.873 & $0.828-2.917$ & 1.712 & 0.21 \\
\hline Punta Baja 85 & 286 & 1.522 & $1.440-1.604$ & 1.103 & $0.200-2.007$ & 1.278 & 0.26 \\
\hline
\end{tabular}

Table 4. Strongylocentrotus purpuratus. Richards function growth parameters $\left(n, S_{\infty}, K\right)$ at sites along the Pacific coast from 1985 to 1987

\begin{tabular}{|lcccrrr|r}
\hline Sample & $\mathrm{n}$ & \multicolumn{2}{c}{$95 \% \mathrm{CI}$} & $S_{\infty} \mathrm{cm}$ & \multicolumn{2}{c|}{$95 \%$ CI } & \multicolumn{1}{c}{$K$} \\
\hline Maalth-sit 2 85 & 0.533 & $-0.130-1.197$ & 5.082 & $4.572-5.592$ & 0.542 & $0.199-0.885$ \\
Maalth-sit 3 85 & -0.375 & $-1.215-0.466$ & 6.015 & $-1.346-13.38$ & 0.130 & $-0.704-0.964$ \\
Maalth-sit 1 87 & -0.393 & $-0.621--0.164$ & 6.024 & $5.233-6.815$ & 0.135 & $0.010-0.260$ \\
Maalth-sit 2 87 & -0.332 & $-0.451--0.213$ & 6.435 & $5.235-7.635$ & 0.063 & $-0.003-0.130$ \\
Maalth-sit 3 87 & 4.288 & $-26.61-35.19$ & 6.721 & $6.240-7.201$ & 0.211 & $0.097-0.324$ \\
Maalth-sit 4 87 & -0.380 & $-0.573--0.186$ & 5.845 & $5.061-6.630$ & 0.095 & $0.014-0.177$ \\
Arena 86 & -0.294 & $-0.376--0.212$ & 5.814 & $5.367-6.262$ & 0.103 & $0.045-0.160$ \\
Arena 87 & -0.246 & $-0.351--0.140$ & 6.544 & $3.805-9.283$ & 0.047 & $-0.073-0.167$ \\
Bodega 85 & -0.346 & $-1.708-1.015$ & 4.043 & $2.371-5.716$ & 0.350 & $-1.092-1.792$ \\
Bodega 86 & -2.223 & $-4.408--0.037$ & 4.443 & $4.275-4.612$ & 0.564 & $0.430-0.698$ \\
McClure & -1.000 & & 4.772 & $2.829-6.715$ & 0.227 & $0.049-0.405$ \\
Baja 85 & -0.274 & $-0.351--0.196$ & 5.695 & $5.124-6.267$ & 0.092 & $0.026-0.159$ \\
\hline
\end{tabular}

duced; this was not possible, so 3 parameters were estimated for all individual samples. Parameter estimates would not converge for data from McClure Beach and so the shape parameter $n$ was arbitrarily set at -1.0 , which is the Brody-Bertalanffy growth model (Table 4).

The scatter of data and fitted lines for both growth models and all samples (Fig. 6) indicate general agreement of the 2 models in the midrange of initial diameter sizes. Differences, however, are apparent at both the upper and lower initial sizes. A lack of very small sea urchins at the time of tagging at most sites precludes comparison of growth for individuals with diameters $<\sim 2.0 \mathrm{~cm}$. The fitted Tanaka lines below an initial diameter of $2 \mathrm{~cm}$ show great variation including no initial diameter with a maximum growth rate, $\Delta \mathrm{D}$, and decline in the rate at smaller sizes. The fitted line for the Bodega 1985 sample (Fig. 6) continues to rise whereas in the 1986 sample a maximum growth rate was estimated to be at an initial diameter of about $1.25 \mathrm{~cm}$. The lack of a peak in the growth rate in the 1985 sample is also indicated by the estimated negative value for the parameter a (Table 3).
A comparison of annual growth of a $3 \mathrm{~cm}$ sea urchin (Fig. 7) showed no pattern with latitude using either the Tanaka or Richards functions. The 1985 sample from the Bodega Marine Reserve as well as the sample from McClure Beach showed the least annual growth as well as being in the central portion of the range of sites studied. Sample sizes for both of the samples, however, were small, 13 and 22 respectively, and the $95 \%$ confidence intervals for the Bodega 1985 sample (Fig. 7) extended into the range of the Bodega 1986 sample. Furthermore, the 1985 sample had a $\Delta t$ of 1.59 yr where the half year included winter months and so would be expected to lower the overall estimate of growth. Using the Richards function (Fig. 7), confidence intervals for both Bodega 1985 and McClure Beach extended into the ranges of the other samples. The significant conclusion from this analysis is that there was no latitudinal trend and growth at the extremes was similar to that in the middle. The highest growth rates occurred in the north at Maalth-sit (Site 4), but overlapping confidence intervals should be taken to mean that there was no difference in growth with latitude. 


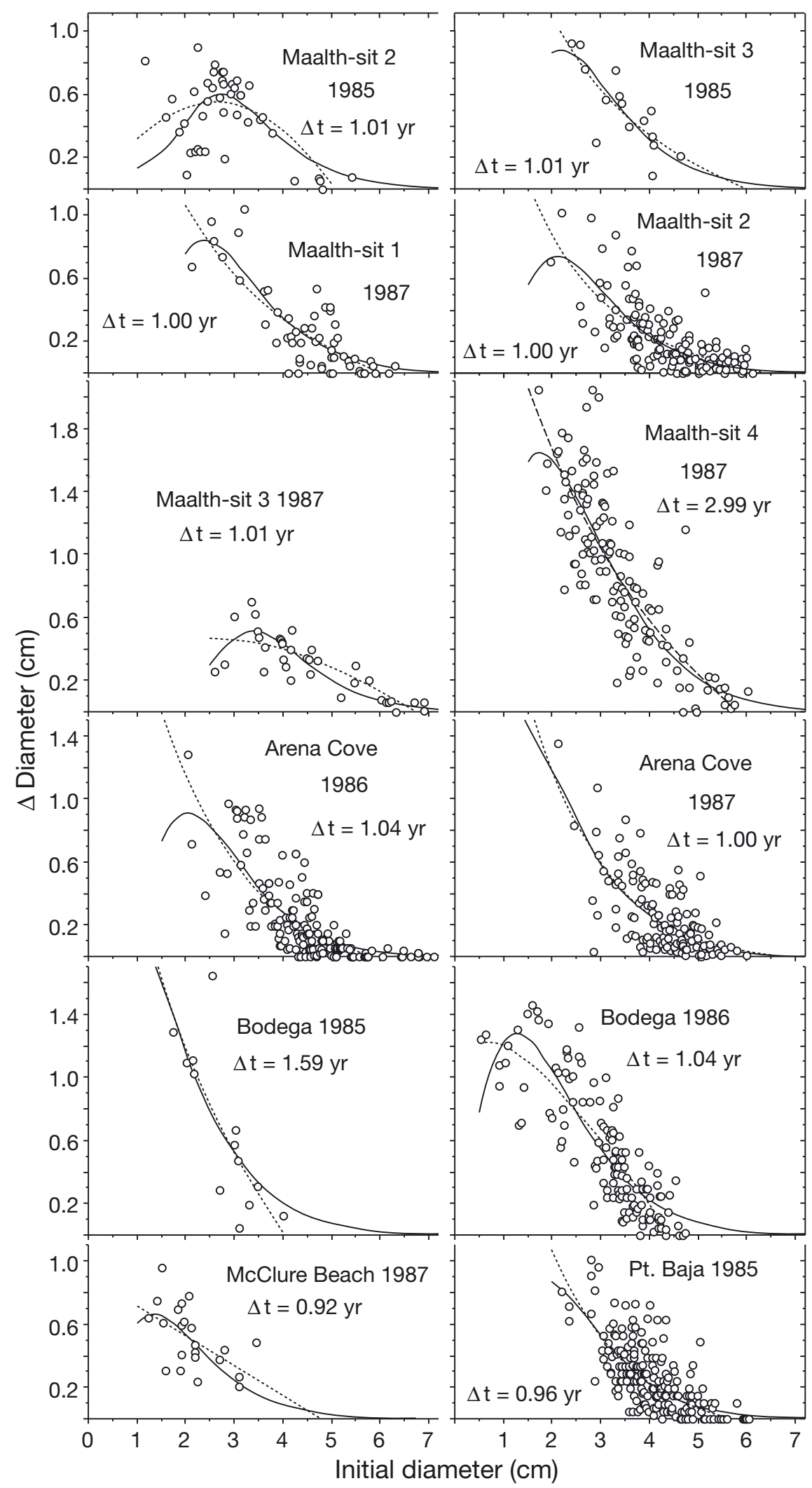

Fig. 6. Strongylocentrotus purpuratus. Scatter plots of $\Delta$ diameter as a function of initial diameter arranged from north to south; Tanaka function with 2 parameters (solid lines) and Richards function with 3 parameters (dashed lines); Maalth-sit (Site 4, Fig. 1), Arena Cove (Site 15), Bodega Marine Reserve (Site 17), McClure Beach (Site 18), and Punta Baja (Site 41). N for each sample is given in Table 3 


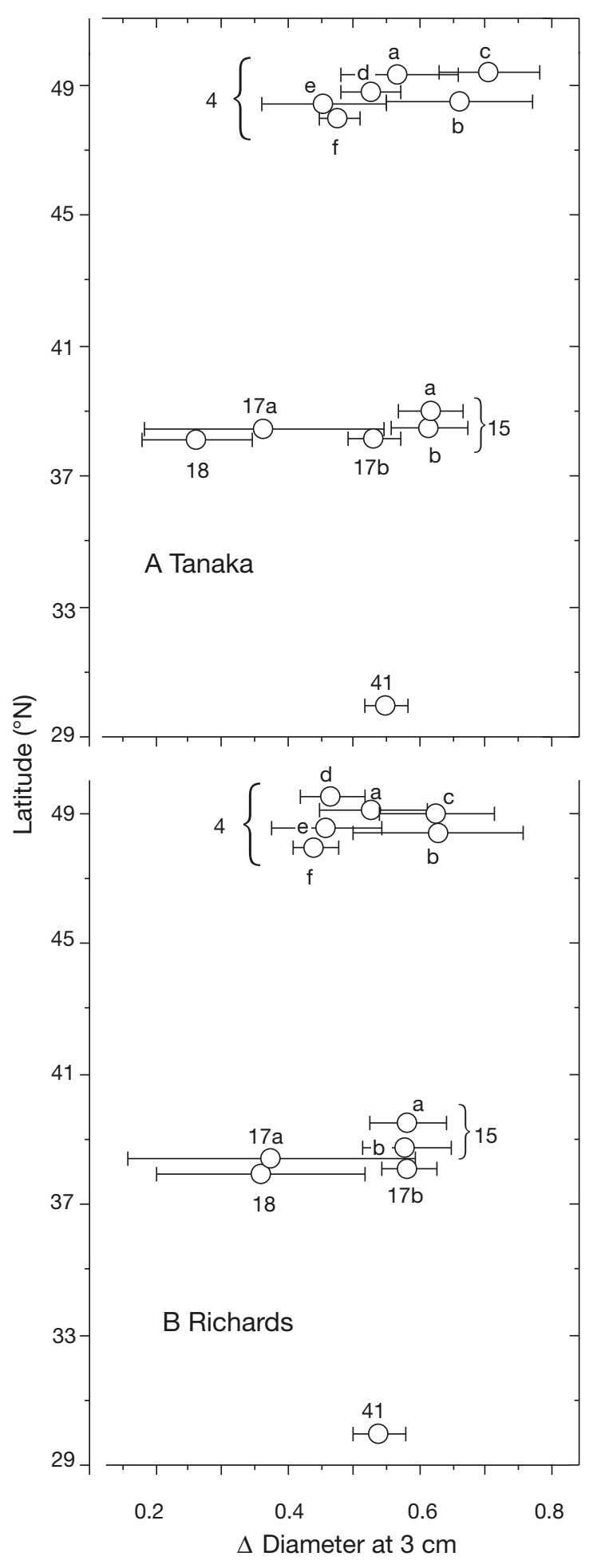

Fig. 7. Strongylocentrotus purpuratus. $\Delta$ diameter estimated at an initial diameter of $3 \mathrm{~cm}$ using (A) the Tanaka function and (B) the Richards function. Error bars are 95\% confidence intervals. Site 4, Maalth-sit: (a) pool_2 1985, (b) pool_3 1985, (c) pool_1 1987,(d) pool_2 1987, (e) pool_3 1987, and (f) pool_4 1987; Site 15, Arena Cove: (a) 1986, (b) 1987; Site 17, Bodega Marine Reserve: (a) 1985, (b) 1986; Site 18, McClure Beach 1987; Site 41, Punta Baja 1985

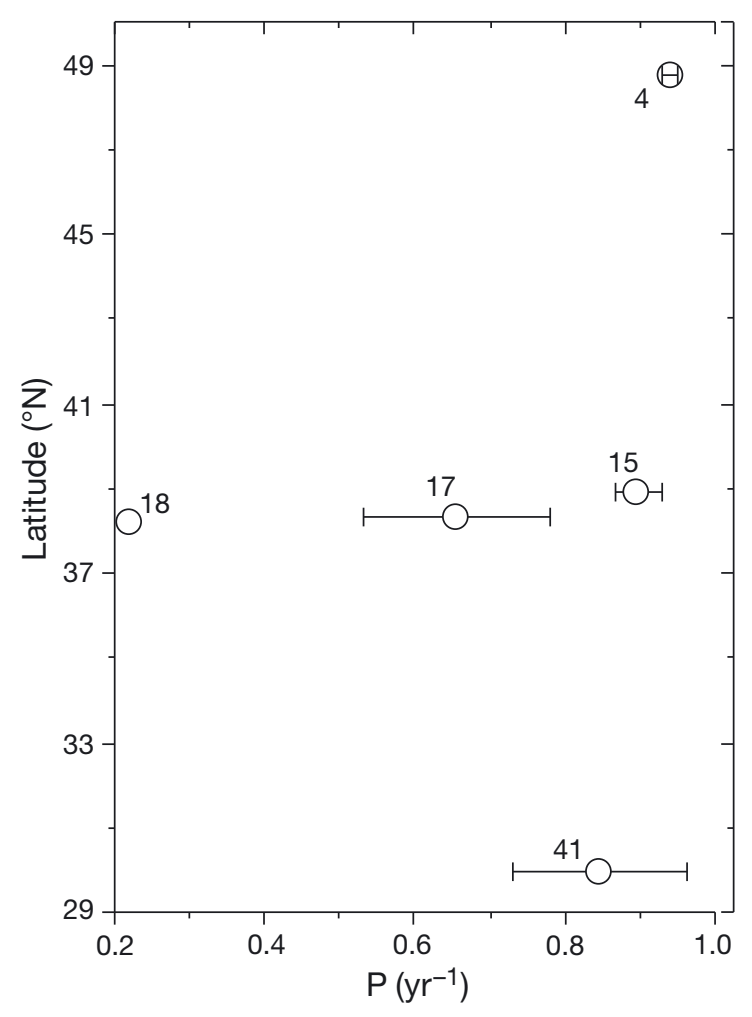

Fig. 8. Strongylocentrotus purpuratus. Survival estimates (annual survival rate, $P \mathrm{yr}^{-1}$ ) based on Tanaka growth parameters and mean diameter of size distributions. Error bars are $\pm 1 \mathrm{SE}$. Site 4, Maalth-sit; Site 17, Bodega Marine Reserve; Site 15, Arena Cove; Site 18, McClure Beach; Site 41, Punta Baja

\section{Annual survival}

The parameter $M$ (Eq. 7) was calculated for each site where growth parameters had been estimated and the mean size of individuals in the first mode was used as $D_{0}$ in Eq. (7). Annual survival rate, $P \mathrm{yr}^{-1},\left(\mathrm{e}^{-M}\right)$ and mean annual survival were calculated for each site. Survival rates were similar at both northern and southern sites (Fig. 8). The estimates for sites between 38 and $39^{\circ} \mathrm{N}$ showed great variation over short distances, with the highest survival estimate for Arena Cove and the lowest for McClure Beach. Survival estimates for Bodega Marine Reserve were intermediate and these 3 sites emphasize that variation in both growth and survival can be expected over short distances.

\section{DISCUSSION}

There are very few studies with sea urchins that span a wide latitudinal range; however, previous studies of Strongylocentrotus purpuratus at some of the sites (e.g. Ebert 1968, 1983, Russell 1987, Ebert \& Russell 1988) showed patterns similar to those presented here. The 
red sea urchin Strongylocentrotus franciscanus, studied from Alaska to southern California (Ebert et al. 1999), showed patterns similar to those found for $S$. purpuratus. Growth varied from north to south, but there was no latitudinal trend; survival was better in the north. The largest red sea urchins were found in the San Juan Islands, Washington, not at the most northern sites in Alaska. The largest red sea urchins have been reported towards the northern end of Vancouver Island (Bureau 1996) and the largest recorded $S$. purpuratus $(10.4 \mathrm{~cm})$ was at a subtidal site off the southern coast of Vancouver Island $\left(48.38^{\circ} \mathrm{N}\right.$, Kramer \& Nordin 1975). Farther north, in Torch Bay, Alaska $\left(58.33^{\circ} \mathrm{N}\right)$, Duggins (1981) did not find purple sea urchins larger than $8 \mathrm{~cm}$. The pattern for both of these Strongylocentrotus species is an increase in the maximum observed size towards the northern end of the range and then a decline out to where the studies have ended.

The number of sites where growth and survival was determined was small; therefore, complex patterns cannot be determined. It is expected, however, that patterns such as the latitudinal changes in maximum diameter (Fig. 5) can be interpreted in terms of growth or survival (or both), which will then focus on the environmental factors that determine these demographic attributes. It also is unknown whether patterns presented here have changed during the past $20 \mathrm{yr}$.

Latitudinal patterns of size, growth, and survival have been described for a number of intertidal and nearshore species. Survival has been reported to increase towards higher latitudes (e.g. Weymouth et al. 1931, Gilbert 1973, Frank 1975, Lewis 1986, Harrington 1987). In general, the pattern for growth rate is the opposite, with a higher growth rate at lower latitudes (e.g. Weymouth et al. 1931, Hall et al. 1974, Frank 1975, Wright 1975, Appeldoorn 1983) but with some complications. Macoma balthica showed an increase in growth rate to the south along the Atlantic coast of the US, but on the European coast growth was highest at intermediate latitudes (Beukema \& Meehan 1985). Maximum size often has been reported as greater at high latitudes (e.g. Weymouth et al. 1931, Frank 1975, Lewis 1986), but the pattern was reversed for M. balthica (Beukema \& Meehan 1985) and Gilman $(2005,2006)$ found no latitudinal trend in maximum size or short-term growth and survival of the limpet Collisella scabra (now Lottia scabra, see Lindberg 2007)

It is unclear whether all of the latitudinal trends that have been reported are correct. For example, Tegula funebralis (now Chlorosoma funebralis, see McLean 2007) showed a trend of increasing maximum size to the north (Frank 1975), but Wright (1975) examined populations both farther north and south. He found the largest individuals at North Cove of Cape Arago,
Oregon $\left(43.30^{\circ} \mathrm{N}\right)$, a decrease in maximum size at Mukkaw Bay, Washington $\left(48.37^{\circ} \mathrm{N}\right)$, and a further decline at Chesterman Beach, Vancouver Island $\left(49.10^{\circ} \mathrm{N}\right)$. This pattern is similar to the pattern shown by Strongylocentrotus spp. It also must be emphasized that all of these studies represent snapshots of the populations and long-term sampling of purple sea urchins has been restricted to just a few sites. For example, at Sunset Bay, Oregon (Site 8, Fig. 1), size structure has been documented since 1964 (Ebert 1968, 1983, unpubl. data) and is strongly influenced by rare recruitment events that change the fraction of Age $\leq 1$ individuals but not maximum size. At another site, False Point, California (Site 39, Fig. 1), where sea urchins have been studied since 1970, density, size structure, and maximum observed size have fluctuated due to both frequent recruitment events and catastrophic mortality (Ebert 1983, unpubl. data).

The models describing population structure across a geographic range by Brown (1984) and Caughley et al. (1988) were developed based on life cycles where offspring develop in the same location as parents (e.g. birds, mammals, plants). These models are not appropriate for marine species with planktonic larvae that spend weeks in the plankton, are obligate dispersers, and hence violate the assumption that offspring develop close to the adults that produced them. Although the shape of the density versus latitude distribution (Fig. 2) tapers at both ends, it should not be considered to support these models. Growth and survival of purple sea urchins as well as other marine invertebrates with planktonic larvae show patterns that are not consistent with the assumptions of the Brown and Caughley models, and so they should not be used to test hypotheses related to latitudinal structure of marine species with planktonic larvae.

Transport of larvae by ocean currents is important and recruitment has been correlated with distance from headlands (Ebert \& Russell 1988). Given the long larval period of $\geq 5$ wk in Strongylocentrotus purpuratus (Strathmann 1978), the patterns of density (Fig. 2) and fraction of Age $\leq 1$ individuals (Fig. 4) are probably best considered in the context of patterns of water movement along the coast (e.g. Ebert 1996, Gaylord \& Gaines 2000). These physical models are useful in focusing attention on currents and coastal topography, but were not developed as general models that include mechanisms responsible for geographic limits or patterns of growth and survival. The obligate planktonic stage uncouples settlement from post-settlement processes and so a site that is good for settlement may or may not be a good site for future growth, survival, and reproduction (Ebert 1982, Gilman 2005).

The model developed by Lewis (1986) comes closest to fitting the purple sea urchin distribution. In this 
model, physical conditions were suitable for adults much farther to the north beyond the normal range and good survival coupled with uncertain recruitment resulted in low densities of large, long-lived individuals. Reproductive seasons lengthened in the south so recruitment failures would be fewer and densities would be higher, but thermal stress would result in smaller and shorter-lived individuals. Some portions of these patterns, such as a general increase in size and improved survival with latitude together with a trend towards increased settlement in the south, have been shown for both red and purple sea urchins (Ebert et al. 1994). Growth rates of red and purple sea urchins, however, do not conform to all aspects of Lewis's model.

Reproduction, based on a gonad index, is difficult to compare across sites because different authors have used different measures, but in general there appears to be no trend in gamete production so northern sites are as productive as southern sites but with substantial variation. For example, sea urchins at Bodega Marine Reserve had gonads smaller than those farther to the south (Lester et al. 2007), but Bodega Marine Reserve was also a site with slower growth than that reported here. Boolootian (1966) determined gonad indices at a site called Shell Beach, close to the Bodega Marine Reserve, as being as high as at sites farther north into Oregon; he concluded that gonad indices were considerably higher for northern populations. The important point is that gamete production is not low in the north and high in the south, which is required in Lewis' (1986) model.

Thermal stress for intertidal species is not a simple function of latitude (e.g. Dahlhoff 2004, Helmuth et al. 2006, Sagarin \& Somero 2006). The tidal wave along the Pacific coast of North America sweeps from south to north and so low tides occur earlier in the south where the lowest summer tides occur before sunrise. Farther north, extreme low tides can occur midmorning and so thermal stress may be greater in the north (Helmuth et al. 2002). The lethal upper limit for Strongylocentrotus purpuratus is about $24^{\circ} \mathrm{C}$ (Farmanfarmaian \& Giese 1963) and there is evidence that purple sea urchins do not tolerate temperatures $\geq 22^{\circ} \mathrm{C}$ for prolonged periods (Ford et al. 1978). For shorter periods, however, individuals can tolerate higher temperatures as shown by Gonor (1968), who measured internal body temperatures for intertidal urchins, but 3 to $5 \mathrm{hr}$ of exposure can be fatal. A sample of 27 individuals at Boiler Bay, Oregon, with internal temperatures above $26^{\circ} \mathrm{C}$ were taken back to Hatfield Marine Laboratory in Newport and held in running seawater where all died within $24 \mathrm{hr}$ (Gonor 1968). There was also substantial mortality in the field at this time: farther south, a mass mortality was observed in the inter- tidal at False Point, La Jolla, California, in 1971 (Ebert 1983), associated with a combination of warm water, high air temperatures, and fall low tides.

Lewis (1986) interpreted southern limits as set by thermal stress and, in combination with changes in nearshore oceanographic processes, this may explain the southern distribution of purple sea urchins. Upwelling can reduce the frequency of high temperature events nearshore and both Punta Baja and Punta San Carlos, Baja California Norte, are within upwelling regions; however, south of Punta San Carlos there is a long stretch of the Baja California coast without predictable upwelling (Zaytsev et al. 2003). Given available information, temperature limitation by physiological stress at the southern end of the distribution is the most reasonable explanation for why Strongylocentrotus purpuratus stops occuring in the intertidal at about Punta San Carlos (Lester et al. 2007) and possibly also the reason for the southern subtidal limit at Isla Cedros.

The cause of the northern limit is unknown, but temperature effects on adults do not seem likely, and in this regard Lewis (1986) is probably correct that adults could be transported many kilometers to the north and they would survive and reproduce. The disconnect between recruitment and adult survival also has been observed across sharp boundaries (e.g. Zacherl et al. 2003, Herbert et al. 2009). Poor recruitment success in Strongylocentrotus purpuratus certainly occurs given the size structure shown at Grant Bay $\left(50.47^{\circ} \mathrm{N}\right)$ or that found by Duggins (1981) in Torch Bay, Alaska $\left(58.33^{\circ} \mathrm{N}\right)$. Recruitment frequency at these northern sites is not known, but it is likely that a combination of temperature effects on development coupled with physical transport of larvae account for highly variable success and at some point total numbers recruited cannot balance adult survival and the geographic limit is reached. This limit may move back and forth along the coast, but farther extension becomes unlikely. Interaction of currents and coastal topography alone, however, cannot be the answer because there are other sea urchin species present in Alaska that have similar larvae. S. franciscanus extends to the west at least to Kodiak Island, Alaska (57 $\mathrm{N}, 153^{\circ} \mathrm{W}$; Mortensen 1943), $S$. droebachiensis and $S$. palidus both are present in Torch Bay as well as farther west along the Alaskan coast, and S. polyacanthus is present farther west in the Aleutian chain (Estes \& Duggins 1995). These species have planktonic larvae physically similar to those of $S$. purpuratus and current patterns are such that they arrive at suitable rocky locations. The limitation of both $S$. purpuratus and $S$. franciscanus may be due to temperature effects on larval development and so fit with the model of Lewis (1986). At $10^{\circ} \mathrm{C}$, early development rates to the pluteus stage were similar for $S$. purpuratus, S. droebachiensis, and S. franciscanus (Strath- 
mann 1987), but Farmanfarmaian \& Giese (1963) reported that no fertilization membrane or development occurred at $5^{\circ} \mathrm{C}$ in $S$. purpuratus.

Appropriate questions for future research are whether demographic patterns shown by Strongylocentrotus purpuratus in the late 1980s have persisted and whether other nearshore species display similar patterns of size, recruitment, growth, and survival. The lack of a cline of growth may be unique to sea urchins or possibly echinoderms generally, but there are no comparable studies that help in answering this. Molluscs certainly have different growth responses and the few available studies show faster growth at lower latitudes. The difference with echinoderms may be related to internal (echinoderms) versus external (molluscs) skeletons. There is a lack of demographic studies over many degrees of latitude for a diversity of marine invertebrates (cf. Sagarin et al. 2006) that could aid in answering these questions, and a single model may not be appropriate.

Acknowledgements. Field and laboratory assistants (in alphabetical order) were: C. Ebert, T. Ebert, F. Jara, M. Lang, and M. Russell. The manuscript was improved by comments by 3 anonymous reviewers. Funding was from the Ocean Sciences Division Biological Oceanography of the US National Science Foundation (grants OCE 84-01415 and OCE-0623934). All of this help and assistance is gratefully acknowledged.

\section{LITERATURE CITED}

Alexander SE, Roughgarden J (1996) Larval transport and population dynamics of intertidal barnacles: a coupled benthic/oceanic model. Ecol Monogr 66:259-275

Appeldoorn RS (1983) Variation in the growth rate of Mya arenaria and its relationship to the environment as analyzed through principal components analysis and the $\omega$ parameter of the von Bertalanffy equation. Fish Bull 81: 75-84

Beukema JJ, Meehan BW (1985) Latitudinal variation in linear growth and other shell characteristics of Macoma balthica. Mar Biol 90:27-33

Boolootian RA (1966) Reproductive physiology. In: Boolootian RA (ed) Physiology of Echinodermata. Wiley Interscience, New York, p 561-613

Brown JH (1984) On the relationship between abundance and distribution of species. Am Nat 124:255-279

Bullock TH (1955) Compensation for temperature in the metabolism and activity of poikilotherms. Biol Rev Camb Philos Soc 30:311-342

Bureau D (1996) Relationship between feeding, reproductive condition, jaw size and density in the red sea urchin, Strongylocentrotus franciscanus. MS thesis, Simon Fraser University, Burnaby

Caughley G, Grice D, Barker R, Brown B (1988) The edge of the range. J Anim Ecol 57:771-785

Clark HL (1913) Echinodermata from Lower California with descriptions of new species. Bull Am Mus Nat Hist 32: 185-236

> Connolly SR, Roughgarden J (1998) A latitudinal gradient in intertidal community structure: evidence for an oceano- graphically based synthesis of marine community theory. Am Nat 151:311-326

Dahlhoff EP (2004) Biochemical indicators of stress and metabolism. Applications for marine ecological studies. Annu Rev Physiol 66:183-207

Defeo O, Cardoso RS (2002) Macroecology of population dynamics and life history traits of the mole crab Emerita brasiliensis in Atlantic sandy beaches of South America. Mar Ecol Prog Ser 239:169-179

Duggins DO (1981) Interspecific facilitation in a guild of benthic marine herbivores. Oecologia 48:157-163

Duggins DO, Quinn JF (1975) Rocky intertidal communities. In: Streveler GP, Whorley IA (eds) Dixon Harbor biological survey. Report to National Park Service, Glacier Bay National Park. National Park Service, Juneau, AK, p 21-41

$>$ Ebert TA (1968) Growth rates of the sea urchin Strongylocentrotus purpuratus related to food availability and spine abrasion. Ecology 49:1075-1091

Ebert TA (1982) Longevity, life history, and relative body wall size in sea urchins. Ecol Monogr 52:353-394

Ebert TA (1983) Recruitment in echinoderms. Echinoderm Stud 1:169-203

Ebert TA (1996) The consequences of broadcasting, brooding, and asexual reproduction in echinoderm metapopulations. Oceanol Acta 19:217-226

Ebert TA (1999) Plant and animal populations. Methods in demography. Academic Press, San Diego, CA

Ebert TA (2008) Longevity and lack of senescence in the red sea urchin Strongylocentrotus franciscanus. Exp Gerontol 43:734-738

Ebert TA, Russell MP (1988) Latitudinal variation in size structure of the west coast purple sea urchin: a correlation with headlands. Limnol Oceanogr 32:286-294

> Ebert TA, Russell MP (1993) Growth and mortality of subtidal red sea urchins (Strongylocentrotus franciscanus) at San Nicolas Island, California, USA: problems with models. Mar Biol 117:79-89

Ebert TA, Southon JR (2003) Red sea urchins (Strongylocentrotus franciscanus) can live over 100 years: confirmation with A-bomb ${ }^{14}$ carbon. Fish Bull 101:915-922

- Ebert TA, Schroeter SC, Dixon JD, Kalvass P (1994) Settlement patterns of red and purple sea urchins (Strongylocentrotus franciscanus and $S$. purpuratus) in California, USA. Mar Ecol Prog Ser 111:41-52

- Ebert TA, Dixon JD, Schroeter SC, Kalvass PE, Richmond NT, Bradbury WA, Woodby DA (1999) Growth and mortality of red sea urchins Strongylocentrotus franciscanus across a latitudinal gradient. Mar Ecol Prog Ser 190:189-209

Estes JA, Duggins DO (1995) Sea otters and kelp forests in Alaska: generality and variation in a community ecological paradigm. Ecol Monogr 65:75-100

Farmanfarmaian A, Giese AC (1963) Thermal tolerance and acclimation in the western purple sea urchin, Strongylocentrotus purpuratus. Physiol Zool 36:237-243

Ford RF, Foreman DG, Grubbs KJ, Kroll CD, Watts DG (1978) Effects of thermal effluent on benthic marine invertebrates determined from long-term simulation studies. In: Thorp JH, Gibbons JW (eds) Energy and environmental stress in aquatic systems. CONF-771114. Tech Info Center, US Dept Energy, Washington, DC, p 546-568

Fortin MJ, Keitt TH, Maurer BA, Taper ML, Kaufman DM, Blackburn TM (2005) Species' geographic ranges and distributional limits: pattern analysis and statistical issues. Oikos 108:7-17

> Francis RICC (1995) An alternative mark-recapture analogue of Schnute's growth model. Fish Res 23:95-111

Frank PW (1975) Latitudinal variation in the life history 
features of the black turban snail Tegula funebralis (Prosobranchia: Trochidae). Mar Biol 31:181-192

Gaston KJ, Chown SL, Evans KL (2008) Ecogeographical rules: elements of a synthesis. J Biogeogr 35:483-500

Gaylord B, Gaines SD (2000) Temperature or transport? Range limits in marine species mediated solely by flow. Am Nat 155:769-789

Gilbert MA (1973) Growth rate, longevity and maximum size of Macoma balthica (L.). Biol Bull 145:119-126

Gilman S (2005) A test of Brown's principle in the intertidal limpet Collisella scabra (Gould, 1846). J Biogeogr 32: 1583-1589

Gilman SE (2006) Life at the edge: an experimental study of a poleward range boundary. Oecologia 148:270-279

Gonor JJ (1968) Temperature relations of central Oregon marine intertidal invertebrates: a prepublication technical report to the Office Naval Research. Department of Oceanography, Oregon State University, Corvallis, OR, available at http://ir.library.oregonstate.edu/dspace/handle/1957/6591

Guo Q, Taper M, Schoenberger M, Brandle J (2005) Spatialtemporal population dynamics across species range: from centre to margin. Oikos 108:47-57

Hall CA Jr, Dollase WA, Corbato CE (1974) Shell growth in Tivela stultorum (Mawe, 1823) and Callista chione (Linnaeus, 1758) (Bivalvia): annual periodicity, latitudinal differences, and diminution with age. Palaeogeogr Palaeoclimatol Palaeoecol 15:33-61

Harrington RJ (1987) Skeletal growth histories of Protothaca staminea (Conrad) and Protothaca grata (Say) throughout their geographic ranges, northeastern Pacific. Veliger 30: $148-158$

Helmuth B, Harley CDG, Halpin PM, O'Donnell M, Hofmann GE, Blanchette CA (2002) Climate change and latitudinal patterns of intertidal thermal stress. Science 298: 1015-1017

> Helmuth B, Broitman BR, Blanchette CA, Gilman S and others (2006) Mosaic patterns of thermal stress in the rocky intertidal zone: implications for climate change. Ecol Monogr 76:461-479

> Herbert RJH, Southward AJ, Clarke RT, Sheader M, Hawkins SJ (2009) Persistent border: an analysis of the geographic boundary of an intertidal species. Mar Ecol Prog Ser 379: $135-150$

Hutchinson GE (1957) Concluding remarks. Cold Spring Harb Symp Quant Biol 22:415-427

Kelly RP, Palumbi SR (2010) Genetic structure among 50 species of the northeastern Pacific rocky intertidal community. PLoS ONE 5:e8594

Kramer DE, Nordin DMA (1975) Physical data from a study of size, weight and gonad quality for the red sea urchin [Strongylocentrotus franciscanus (Agassiz)] over a oneyear period. Fish Res Board Can Manuscr Rep Ser 1372: $1-91$

- Lester SE, Gaines SD, Kinlan BP (2007) Reproduction on the edge: large-scale patterns of individual performance in a marine invertebrate. Ecology 88:2229-2239

Lewis JR (1986) Latitudinal trends in reproduction, recruitment and population characteristics of some rocky littoral molluscs and cirripedes. Hydrobiologia 142:1-13

Lindberg DR (2007) Patellogastropoda. In: Carlton JT (ed) The Light and Smith manual. Intertidal invertebrates from central California to Oregon. University of California Press, Berkeley, CA, p 753-761

Lonsdale DJ, Levinton SJ (1985) Latitudinal differentiation in copepod growth: an adaptation to temperature. Ecology 66:1397-1407
Macdonald PD, Pitcher TJ (1979) Age-groups from size-frequency data: a versatile and efficient method of analyzing distribution mixtures. J Fish Res Board Can 36:987-1001

McLean JH (2007) Gastropods. In: Carlton JT (ed) The Light and Smith manual. Intertidal invertebrates from central California to Oregon. University of California Press, Berkeley, CA, p 713-753

Miller BA, Emlet RB (1997) Influence of nearshore hydrodynamics on larval abundance and settlement of sea urchins Strongylocentrotus franciscanus and $S$. purpuratus in the Oregon upwelling zone. Mar Ecol Prog Ser 148:83-94

> Miller BA, Emlet RB (1999) Development of newly metamorphosed juvenile sea urchins (Strongylocentrotus franciscanus and $S$. purpuratus): morphology, the effects of temperature and larval food ration, and a method for determining age. J Exp Mar Biol Ecol 235:67-90

Mortensen Th (1943) A monograph of the echinoidea, Vol III, Part 3. Camarodonta II, Echinidae, Strongylocentrotidae, Parasaleniidae, Echinometridae. CA Reitzel, Copenhagen

> Olivares-Bañuelos NC, Enríquez-Paredes LM, Ladah LB, De La Rosa-Vélez J (2008) Population structure of purple sea urchin Strongylocentrotus purpuratus along the Baja California peninsula. Fish Sci 74:804-812

Parmesan C, Gaines S, Gonzalez L, Kaufman DM, Kingsolver J, Peterson AT, Sagarin R (2005) Empirical perspectives on species borders: from traditional biogeography to global change. Oikos 108:58-75

> Richards FJ (1959) A flexible growth function for empirical use. J Exp Bot 10:290-300

> Richards SA, Possingham HP, Noye BJ (1995) Larval dispersion along a straight coast with tidal currents: complex distribution patterns from a simple model. Mar Ecol Prog Ser 122:59-71

Rowley RJ (1989) The settlement, recruitment, and early growth and mortality of the purple sea urchin, Strongylocentrotus purpuratus, and the red sea urchin, S. franciscanus, in a kelp bed and urchin barren ground. $\mathrm{PhD}$ dissertation, University of California Santa Barbara

> Russell MP (1987) Life history traits and resource allocation in the purple sea urchin Strongylocentrotus purpuratus (Stimpson). J Exp Mar Biol Ecol 108:199-216

Sagarin RD, Gaines SD (2002) Geographical abundance distributions of coastal invertebrates: using one-dimensional ranges to test biogeographic hypotheses. J Biogeogr 29: 985-997

Sagarin RD, Somero GN (2006) Complex patterns of expression of heat-shock protein 70 across the southern biogeographical ranges of the intertidal mussel Mytilus californianus and snail Nucella ostrina. J Biogeogr 33:622-630

Sagarin RD, Gaines SD, Gaylord B (2006) Moving beyond assumptions to understand abundance distributions across the ranges of species. Trends Ecol Evol 21:524-530

Samis KE, Eckert CG (2007) Testing the abundant center model using range-wide demographic surveys of two coastal dune plants. Ecology 88:1747-1758

Schnute J (1981) A versatile growth model with statistically stable parameters. Can J Fish Aquat Sci 38:1128-1140

Strathmann R (1978) Length of pelagic period in echinoderms with feeding larvae from the northeast Pacific. J Exp Mar Biol Ecol 34:23-27

Strathmann MF (1987) Reproduction and development of marine invertebrates of the northern Pacific coast. University of Washington Press, Seattle, WA

SYSTAT (2004) SYSTAT 11. SYSTAT Software, Richmond, CA

Tanaka M (1982) A new growth curve which expresses infinite increase. Publ Amakusa Mar Biol Lab 6:167-177 
Tanaka M (1988) Eco-physiological meaning of parameters of ALOG growth curve. Publ Amakusa Mar Biol Lab 9: 103-106

> Wares JP, Gaines SD, Cunningham CW (2001) A comparative study of asymmetric migration events across a marine biogeographic boundary. Evolution 55:295-306

Weymouth FW, McMillin HC, Rich WH (1931) Latitude and relative growth in the razor clam, Siliqua patula. J Exp Biol 8:228-249

Whittaker RH (1960) Vegetation of the Siskiyou Mountains, Oregon and California. Ecol Monogr 30:279-338

Editorial responsibility: John Lawrence,

Tampa, Florida, USA
Wright RC (1975) Variations in size structure along a latitudinal cline, growth rate and respiration in the snail Tegula funebralis. MS thesis, San Diego State University, San Diego, CA

Zacherl D, Gaines SD, Lonhart SI (2003) The limits to biogeographical distributions: insights from the northward range extension of the marine snail, Kelletia kelletii (Forbes, 1852). J Biogeogr 30:913-924

Zaytsev O, Cervantes-Duarte R, Montante O, Gallegos-Garcia A (2003) Coastal upwelling activity on the Pacific shelf of the Baja California peninsula. J Oceanogr 59:489-502

Submitted: September 30, 2009; Accepted: February 16, 2010 Proofs received from author(s): April 29, 2010 